\title{
Sacroiliitis detected by bone scintiscanning: a clinical, radiological, and scintigraphic follow-up study
}

\author{
IAN M. CHALMERS, * BRIAN C. LENTLE, JOHN S. PERCY, \\ AND ANTHONY S. RUSSELL
}

From the Rheumatic Disease Unit, Department of Medicine, University of Alberta, and the Department of Nuclear Medicine, Dr W.W. Cross Cancer Institute, University of Alberta, Edmonton, Alberta, Canada

SUMMARY Twenty-four patients had abnormal sacroiliac joints detected by quantitative sacroiliacio scintigraphy but no radiological evidence of sacroiliitis on original investigation. We studied therp again after intervals of 12 to 36 months. Four patients developed radiological change. Two young HLA B27-positive men had undoubted ankylosing spondylitis, and a young woman had possible ankylosing spondylitis. A middle-aged man had changes that could be attributed to post-traumatie osteoarthrosis. Of the remaining 20 cases 15 had symptoms and signs suggestive of inflammator $\vec{x}$ disease of the axial skeleton (and peripheral arthropathy in 5 cases). The sexes were affected equali ( 8 females, 7 males), and only 2 of the 15 were B27-positive. The response to anti-inflammator medication was generally good to excellent, and scintiscans tended to improve. Of the remaining patients, 3 had mechanical or traumatic problems, and in 2 there was no explanation for the abnormal sacroiliac scintiscan. We conclude that quantitative sacroiliac scintigraphy may detect ankylosing spondylitis prior to the development of radiological change and that it can identify an organio basis for backache in patients with a spondylitis-like syndrome. The clinical circumstances must bo taken into account, as scintigraphic abnormalities are not diagnostic of any specific disease entity.

Bone scanning with $99 \mathrm{~m}$ technetium-labelled stannous pyrophosphate is a sensitive means of detecting disease of the axial skeleton (Lentle et al., 1976). The technique is particularly applicable to the sacroiliac joints, where the uptake of radiotracer can be accurately quantitated in relation to the uptake by the central sacrum (Lentle et al., 1977a; Namey et al., 1977). The resultant sacroiliac joint to sacrum uptake ratios are clearly raised in a number of diseases associated with sacroiliitis (Russell et al., 1975; Russell et al., 1976a; Russell et al., 1976b; Lentle et al., 1977b; Barraclough et al., 1977; Russell et al., 1977; Davis et al., in press), and, while most of the patients studied had radiological changes in their sacroiliac joints, an appreciable number did not. The finding of scintigraphic evidence of sacroiliitis in patients with appropriate clinical symptoms and signs but who did not have radiological abnormality suggests that the scintiscan may be a valuable

Accepted for publication 25 May 1978.

Correspondence to Dr A. S. Russell, 9-112 Clinical Sciences Building, University of Alberta, Edmonton, Alberta, Canada T6G 2 G3.

*Present address: Department of Medicine, University of Natal, Durban, South Africa. tool for the early diagnosis of ankylosing spondylitis and similar conditions. To test this postulate we have followed up a number of patients with scintigraphic sacroiliitis and radiologically normal sacroilia joints, and we report our findings in this paper.

\section{Patients and methods}

Our cases were selected from a series of 172 patien $\mathbb{B}$ seen prior to 1976 who had abnormal sacroiliar joints on bone scanning. We excluded all those wit radiological abnormalities and all who had a diagr nosis of psoriatic spondylitis or Reiter's syndrome and were left with 37 names. From these we traced 27 patients who were willing to participate in the project. Three were found on review not to fulfil the criteria for inclusion: 2 had scintiscans that were probably normal for the patients' degree of skeletat immaturity, and 1 had radiological abnormalities evident on the original films.

The final study population of 24 patients comprise $\$$ 12 men and 12 women with a mean age of 39 years (range 19 to 59). The median interval betwee original investigation and follow-up was 22 months (range 12 to 36 ). 
Each patient's records were reviewed and relevant clinical and laboratory data noted. The patients were then examined clinically with particular attention to the axial skeleton. Measurements were made of the expansion of a $10 \mathrm{~cm}$ segment of lumbar spine (normal $>5 \mathrm{~cm}$ ) and of the finger-floor distance on forward flexion (normal $=0$ ) and of chest expansion (normal $>2.5 \mathrm{~cm}$ ). Other lumbar movements and cervical spine mobility were assessed subjectively. Tenderness was detected by direct pressure and stressing of the sacroiliac joints. Physical signs detected by these manoeuvres may be the result of a variety of pathological processes. There is unfortunately no reliable clinical method for specifically identifying inflammatory disease, so one has to rely on these techniques in conjunction with the patient's symptoms.

In each case radiographs of pelvis and lumbar spine were obtained and a bone scan, including measurement of sacroiliac joint to sacrum uptake ratios (SI:S ratios), was made as previously described (Russell et al., 1975; Lentle et al., 1977a); new and old radiographs were read 'blind' and in random order by 2 independent observers experienced in the radiological assessment of sacroiliac joints. The appearances were graded according to the New York criteria (Bennett and Wood, 1968). Differences in interpretation were resolved by a combined review by the 2 observers who were unaware of the nature of the discrepancy.

Tissue typing by standard techniques (Russell et al., 1974) was carried out on all patients.

\section{Results}

We have classified the patients into 2 groups on the basis of the results of the radiological investigation. Group I comprises 4 patients who developed new radiological abnormalities. In the 20 patients in group II, no radiological changes were found. In describing SI:S ratios, we have used a value of $1 \cdot 32$ as the upper limit of normal. This figure is based on the readings obtained from a previously studied group of subjects without articular disease (Lentle et al., 1977a) and supersedes the initially recommended figure of $1 \cdot 20$ (Russell et al., 1975).

GROUP I: NEW RADIOLOGICAL ABNORMALITY The scintiscan and radiological data on the 4 patients in this group are listed in Table 1. Clinical details are as follows.

Case 1. This 34-year-old man was originally seen with a 14-month history of low backache and morning stiffness following a minor injury. Back movements were markedly restricted. Radiological studies included a myelogram which was normal. His sedimentation rate was $29 \mathrm{~mm} / \mathrm{h}$ (Wintrobe), and tissue typing revealed the presence of the HLA B27 antigen. At follow-up 18 months later he was entirely asymptomatic on treatment with fenoprofen. He had a full range of movement of his lumbar spine and his chest expansion was $8 \mathrm{~cm}$.

Case 2. This 25-year-old man presented with a 4-year history of intermittent pain in the hips. For the month prior to being seen he had experienced pain and stiffness of the left hip and lower back. Several months earlier he had had his first attack of acute iritis. Back movements were markedly reduced and there was a finger-floor distance of $30 \mathrm{~cm}$ at maximal forward flexion. Chest expansion was $4 \mathrm{~cm}$. The sedimentation rate was $14 \mathrm{~mm} / \mathrm{h}$, and serological tests for rheumatoid arthritis and lupus erythematosus were negative. At follow-up 32 months later he had minimal pain but still experienced prolonged morning stiffness despite phenylbutazone therapy. Back movements and chest expansion were unchanged. There was a mild degree of painful restriction of hip movements. There was no tenderness of the sacroiliac joints or lumbar spine. He had had several attacks of iritis, and was just recovering from the most recent of these. Tissue typing performed at follow-up showed the presence of the HLA B27 antigen. This patient has a brother who is B27-positive and has ankylosing spondylitis.

Case 3. This 33-year-old woman presented with a 2-year history of low back pain and morning stiffness.

Table 1 Scintiscan and radiological findings in group $I$

\begin{tabular}{|c|c|c|c|c|c|c|}
\hline \multirow{2}{*}{\multicolumn{2}{|c|}{ Case }} & \multirow{2}{*}{\multicolumn{2}{|c|}{ Scintiscan findings }} & \multirow{2}{*}{ Other sites of uptake } & \multirow{2}{*}{\multicolumn{2}{|c|}{ Radiological appearances }} \\
\hline & & & & & & \\
\hline \multirow{2}{*}{1} & & & & & & \\
\hline & Follow-up & $1 \cdot 88$ & $1 \cdot 60$ & Ankles, mid-dorsal spine & Grade 2 & Grade 2 \\
\hline \multirow{2}{*}{2} & Original & $1 \cdot 90$ & $2 \cdot 04$ & Nil & Normal & Normal \\
\hline & Follow-up & $1 \cdot 37$ & $1 \cdot 42$ & Nil & Normal & Grade 2 \\
\hline \multirow[t]{2}{*}{3} & Original & $1 \cdot 40$ & $1 \cdot 35$ & Nil & Normal & Normal \\
\hline & Follow-up & $1 \cdot 37$ & $1 \cdot 30$ & Nil & Normal & Grade 2 \\
\hline \multirow[t]{2}{*}{4} & Original & $1 \cdot 42$ & $1 \cdot 25$ & $\begin{array}{l}\mathbf{R} \text { elbow, wrists, } L \text { knee, } \\
\mathbf{R} \text { ankle, } \mathbf{R} \text { tarsus }\end{array}$ & Normal & Normal \\
\hline & Follow-up & $1 \cdot 33$ & $1 \cdot 18$ & Knees, $\mathbf{R}$ ankle, $\mathbf{R}$ tarsus, elbows & Grade 2 & Normal \\
\hline
\end{tabular}


The spine was normal on clinical examination. The sedimentation rate was $6 \mathrm{~mm} / \mathrm{h}$. Tissue typing was negative for the HLA B27 antigen. At followup 18 months later she complained of intermittent low backache and pain in the neck associated with morning stiffness of up to 1 hour's duration. She had not taken any anti-inflammatory medication since experiencing an 'allergic' reaction to indomethacin some months previously. Both sacroiliac joints were tender to palpation, the right more than the left. Movements of the lumbar spine were slightly limited. Chest expansion was $6 \mathrm{~cm}$. Cervical spine movements were normal.

Case 4. After a motor accident many years previously this 56-year-old man developed pain in the left knee, right ankle, and right elbow. There were no back symptoms. Radiologically there were degenerative changes in the clinically involved joints. During the year following initial investigation the patient experienced severe backache, but this disappeared promptly after a total knee replacement. When seen at follow-up 26 months after the original studies he was entirely asymptomatic, with a clinically normal axial skeleton. This patient does not have the HLA B27 antigen.

\section{GROUP II: RADIOLOGICALLY NORMAL}

SACROILIAC JOINTS

We have further classified this group of 20 patient into 3 subgroups on the basis of their clinica presentation.

A: Presentation with backache. Ten patients presented with low backache associated with earl $\vec{b}$ morning stiffness or exacerbation. All but 2 had limited lumbar spine mobility. One of the latteg patients had pain in the dorsal spine and reduced chest expansion. Nine of the patients had take $\vec{P}$ nonsteroidal anti-inflammatory drugs with good t $\omega_{0}$ excellent relief in 8 and persistent severe symptoms in 1 case. At the time of follow-up 4 of the asympto matic patients had normal spinal movements. Two had discontinued their anti-inflammatory medication? One young woman was on prednisone for Crohn's disease of the small bowel, and she too had no back symptoms at follow-up. Further data on these patients are given in Table 2 .

Table 2 Scintiscan and other data on patients in group IIA

\begin{tabular}{|c|c|c|c|c|c|c|c|c|c|c|}
\hline \multirow[b]{3}{*}{ Case } & \multirow[b]{3}{*}{ Sex } & \multirow[b]{3}{*}{$\begin{array}{l}\text { Age } \\
(y r)\end{array}$} & \multirow[b]{3}{*}{$\begin{array}{l}\text { Duration of } \\
\text { symptoms at } \\
\text { original } \\
\text { investigation }\end{array}$} & \multicolumn{6}{|c|}{ Scintiscan findings } & \multirow[b]{3}{*}{ Other features } \\
\hline & & & & \multicolumn{3}{|l|}{ Original } & \multicolumn{3}{|c|}{ Follow-up } & \\
\hline & & & & $\begin{array}{l}\text { L SI:S } \\
\text { ratio }\end{array}$ & $\begin{array}{l}\text { R SI:S } \\
\text { ratio }\end{array}$ & $\begin{array}{l}\text { Other sites } \\
\text { of uptake }\end{array}$ & $\begin{array}{l}\text { L SI:S } \\
\text { ratio }\end{array}$ & $\begin{array}{l}R \text { SI:S } \\
\text { ratio }\end{array}$ & $\begin{array}{l}\text { Other sites } \\
\text { of uprake }\end{array}$ & \\
\hline 5 & $\mathbf{M}$ & 19 & $9 \mathrm{mo}$ & $1 \cdot 39$ & 1.50 & $\begin{array}{l}\text { Hips, knees, } \\
\text { shoulders, } \\
\text { sternocla- } \\
\text { vicular joints }\end{array}$ & $1 \cdot 20$ & $1 \cdot 11$ & Nil & $\begin{array}{l}\text { Normal myelogram } \\
\text { B27-positive }\end{array}$ \\
\hline 6 & $\mathbf{F}$ & 22 & $2 \mathrm{yr}$ & 1.47 & $1 \cdot 41$ & Nil & $1 \cdot 39$ & $1 \cdot 32$ & Nil & $\begin{array}{l}\text { On no treatment. In } \\
\text { clinical remission }\end{array}$ \\
\hline 7 & $\mathbf{F}$ & 26 & $3 \mathrm{yr}$ & $1 \cdot 34$ & $1 \cdot 33$ & Nil & 1.08 & 1.09 & Nil & $\begin{array}{l}\text { Crohn's disease. On } \\
\text { prednisone }\end{array}$ \\
\hline 8 & $\mathbf{F}$ & 28 & $5 \mathrm{yr}$ & 1.44 & $1 \cdot 29$ & Nil & $1 \cdot 30$ & $1 \cdot 34$ & $\mathrm{Nil}$ & $\begin{array}{l}\text { Dorsal spine pain. } \\
\text { Reduced chest } \\
\text { expansion. Sed, rate }\end{array}$ \\
\hline 9 & $\mathbf{M}$ & 31 & $9 \mathrm{mo}$ & 1.42 & 1.49 & $\begin{array}{l}\text { Mid-dorsal } \\
\text { spine, } R \text { elbow }\end{array}$ & $1 \cdot 36$ & $1 \cdot 37$ & Nil & \\
\hline 10 & $\mathbf{F}$ & 34 & $2 \mathrm{yr}$ & $1 \cdot 40$ & $1 \cdot 35$ & Nil & $1 \cdot 50$ & $1 \cdot 41$ & Shoulders & $\begin{array}{l}\text { No improvement on } \\
\text { anti-inflammatory } \\
\text { drugs }\end{array}$ \\
\hline 11 & $\mathbf{M}$ & 40 & $4 \mathrm{mo}$ & $1 \cdot 40$ & $1 \cdot 45$ & $\begin{array}{l}\text { L sterno- } \\
\text { clavicular } \\
\text { joint }\end{array}$ & $1 \cdot 18$ & $1 \cdot 21$ & $\begin{array}{l}\text { Knees, ankles, } \\
\text { shoulders, } \\
\text { elbows, } \\
\text { sternocla- } \\
\text { vicular joints }\end{array}$ & $\begin{array}{l}\text { On no treatment. In } \\
\text { clinical remission. } \\
\text { Initial sed. rate } 21\end{array}$ \\
\hline 12 & $\mathbf{F}$ & 41 & $1 \mathrm{yr}$ & $1 \cdot 53$ & $1 \cdot 36$ & $\begin{array}{l}\text { L ankle, knees, } \\
\text { hips, } \\
\text { shoulders, } \\
\text { elbows, } \\
\text { wrists, mid- } \\
\text { dorsal spine }\end{array}$ & $1 \cdot 40$ & $1 \cdot 31$ & $\begin{array}{l}\text { Ankles, knees, } \\
\text { hips, } \\
\text { shoulders, } \\
\text { elbows, } \\
\text { wrists, mid- } \\
\text { dorsal spine }\end{array}$ & \\
\hline 13 & $\mathbf{M}$ & 43 & $2 \mathrm{yr}$ & 1.48 & 1.48 & Nil & $1 \cdot 25$ & $1 \cdot 18$ & $\begin{array}{l}\text { Ankles, knees, } \\
\mathrm{R} \text { tarsus }\end{array}$ & $\begin{array}{l}\text { Has a son with } \\
\text { ankylosing spondylitis }\end{array}$ \\
\hline 14 & $\mathbf{M}$ & 53 & $6 \mathrm{mo}$ & $1 \cdot 36$ & 1.43 & Nil & $1 \cdot 40$ & $1 \cdot 38$ & Nil & $\begin{array}{l}\text { Back movements } \\
\text { normal initially but } \\
\text { later restricted }\end{array}$ \\
\hline
\end{tabular}


B: Presentation with peripheral joint pain. Five patients presented with pain and early morning stiffness mainly affecting large peripheral joints. There was no evident joint swelling or deformity. Three of the patients complained of backache and all 5 had limitation of lumbar movement. One had no measurable chest expansion. All had taken nonsteroidal anti-inflammatory drugs but were still mildly symptomatic at follow-up. Three still had abnormal back movements. None had symptoms to suggest eye, skin, genitourinary, or chronic inflammatory bowel disease. All had normal sedimentation rates and negative latex tests for rheumatoid factor. Further data are presented in Table 3.

$C$ : Presentation with symptoms thought not to be inflammatory in origin. The remaining 5 patients presented with back or peripheral joint pain thought in each case to be caused by some process other than chronic inflammation. Their clinical and scintiscan data are summarised in Table 4.

Table 3 Scintiscan and other data on patients in group IIB

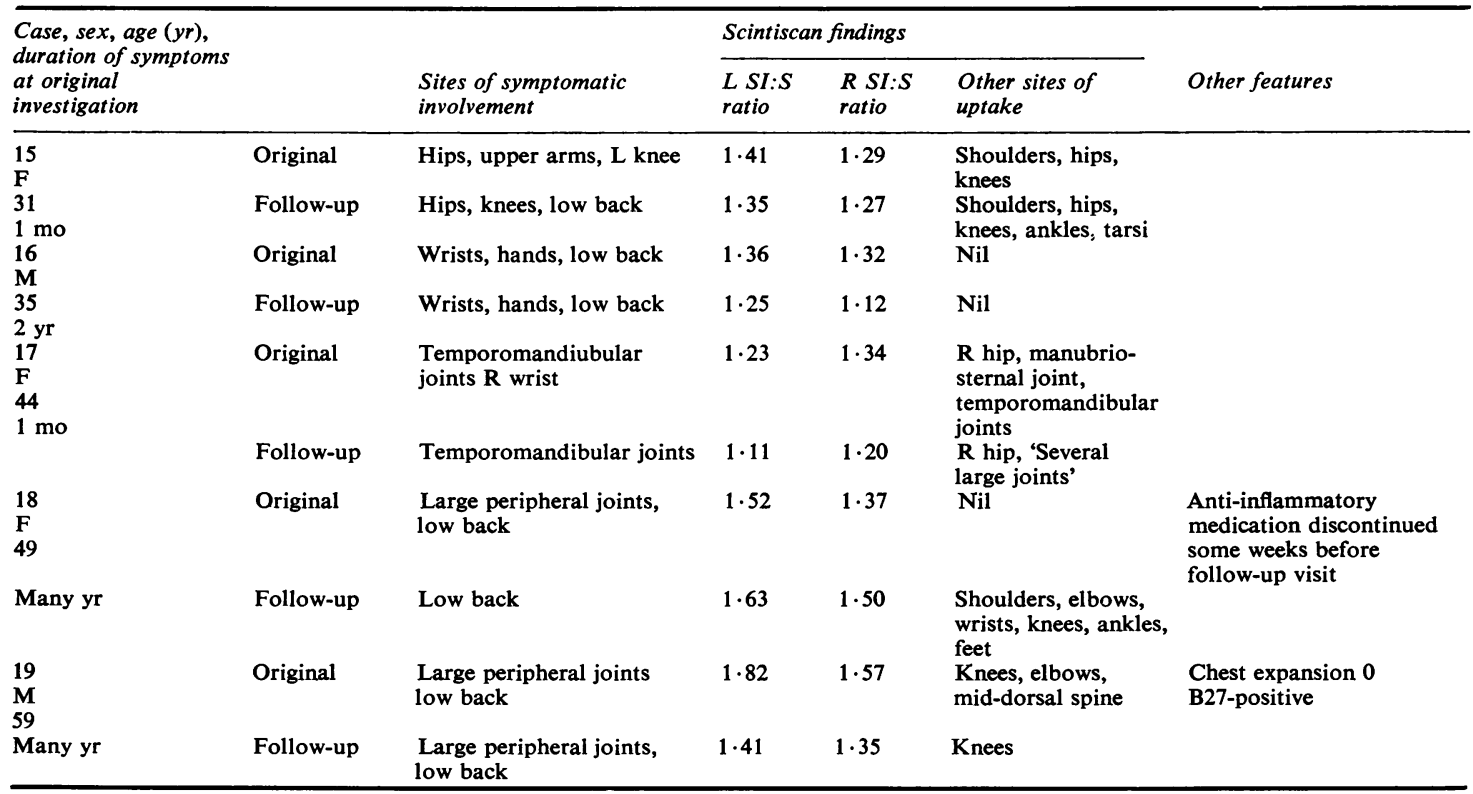

Table 4 Clinical and scintiscan data on patients in group IIC

\begin{tabular}{|c|c|c|c|c|c|}
\hline \multirow{2}{*}{$\begin{array}{l}\text { Case, sex, age }(y r), \\
\text { duration of symptoms } \\
\text { at original } \\
\text { investigation }\end{array}$} & \multirow[b]{2}{*}{ Clinical features } & & \multicolumn{3}{|c|}{ Scintiscan findings } \\
\hline & & & $\begin{array}{l}L S I: S \\
\text { ratio }\end{array}$ & $\begin{array}{l}\text { R SI:S } \\
\text { ratio }\end{array}$ & $\begin{array}{l}\text { Other sites of } \\
\text { uptake }\end{array}$ \\
\hline $\begin{array}{l}20 \\
\text { F } \\
34 \\
1 \text { yr }\end{array}$ & $\begin{array}{l}\text { Mild rheumatic arthritis since teens. Back and neck } \\
\text { pain not associated with morning stiffness following } \\
\text { motor accident. Sed rate } 12 \text {. Rheumatoid latex } \\
\text { negative }\end{array}$ & $\begin{array}{l}\text { Original } \\
\text { Follow-up }\end{array}$ & $\begin{array}{l}1 \cdot 37 \\
1 \cdot 52\end{array}$ & $\begin{array}{l}1 \cdot 56 \\
1 \cdot 35\end{array}$ & $\begin{array}{l}\text { Elbows, wrists, hips } \\
\text { Ankles, knees, hips, } \\
\text { elbows, wrists }\end{array}$ \\
\hline $\begin{array}{l}21 \\
\text { F } \\
35 \\
\text { Many yr }\end{array}$ & $\begin{array}{l}\text { Low backache. No morning stiffness. Marked } \\
\text { increase in lumbar lordosis }\end{array}$ & $\begin{array}{l}\text { Original } \\
\text { Follow-up }\end{array}$ & $\begin{array}{l}1 \cdot 58 \\
1 \cdot 47\end{array}$ & $\begin{array}{l}1 \cdot 46 \\
1 \cdot 37\end{array}$ & $\begin{array}{l}\mathrm{Nil} \\
\mathrm{Nil}\end{array}$ \\
\hline $\begin{array}{l}22 \\
\mathrm{M} \\
50 \\
4 \mathrm{yr}\end{array}$ & $\begin{array}{l}\text { Crush fractures of dorsal spine with marked } \\
\text { kyphosis. Low backache. No morning stiffness }\end{array}$ & $\begin{array}{l}\text { Original } \\
\text { Follow-up }\end{array}$ & $\begin{array}{l}1 \cdot 40 \\
1 \cdot 29\end{array}$ & $\begin{array}{l}1 \cdot 37 \\
1 \cdot 26\end{array}$ & $\begin{array}{l}\text { Nil } \\
\text { Nil }\end{array}$ \\
\hline $\begin{array}{l}23 \\
F \\
54\end{array}$ & $\begin{array}{l}\text { Calcific periarthritis of shoulders. No back symptoms. } \\
\text { Slight reduction in lumbar flexion }\end{array}$ & $\begin{array}{l}\text { Original } \\
\text { Follow-up }\end{array}$ & $\begin{array}{l}1 \cdot 37 \\
1 \cdot 45\end{array}$ & $\begin{array}{l}1 \cdot 41 \\
1 \cdot 31\end{array}$ & $\begin{array}{l}\text { Shoulders } \\
\text { Nil }\end{array}$ \\
\hline $\begin{array}{l}24 \\
\text { M } \\
58 \\
33 \text { yr }\end{array}$ & $\begin{array}{l}\text { Long history of back and joint pain. No morning } \\
\text { stiffness. Psychiatric problems. No objective signs of } \\
\text { disease }\end{array}$ & $\begin{array}{l}\text { Original } \\
\text { Follow-up }\end{array}$ & $\begin{array}{l}1 \cdot 35 \\
1 \cdot 14\end{array}$ & $\begin{array}{l}1 \cdot 34 \\
1 \cdot 13\end{array}$ & $\begin{array}{l}\text { Nil } \\
\text { Nil }\end{array}$ \\
\hline
\end{tabular}




\section{Discussion}

In this investigation we have demonstrated that in some patients scintiscan abnormalities may foreshadow the development of radiological changes in the sacroiliac joints. There can be little doubt that cases 1 and 2 described above have ankylosing spondylitis. Case 1 fulfils the New York criteria (Russell et al., 1977) for the diagnosis of definite ankylosing spondylitis. This is not so for case 2, as he has only unilateral grade 2 changes. However, he has other attributes (for example, possession of the HLA B27 antigen and a positive family history) which add support to the diagnosis. These 2 cases, therefore, show that an abnormal sacroiliac bone scan may be a precursor to undoubted ankylosing spondylitis. Like case 2 , case 3 had radiological involvement of only one sacroiliac joint at followup but she lacked the additional features of case 2 . She can therefore be regarded as having no more than possible ankylosing spondylitis, but she does show that scintiscan aphormalities may precede radiological changes in the sacroiliac joints.

The patients in groups IIA and IIB (cases 5 to 19) are of some interest. Since none of them developed radiological changes they cannot be regarded as having ankylosing spondylitis, but their illnesses do appear to represent a fairly distinct clinical syndrome. All had back pain, with or without peripheral arthralgia, at some time, and most had measurable changes in spinal movement. An inflammatory cause for the pain was suggested by the presence of morning stiffness and the prompt relief of pain in most cases by nonsteroidal anti-inflammatory drugs. Of patients who had discontinued their medication 1 was symptomatic while owners were in sustained remission. No patient had a history or physical signs to suggest a mechanical cause for their pain. Sedimentation rates for the most part were normal, as they may be in ankylosing spondylitis (Ogryzlo, 1972), and other laboratory tests were negative. Apart from one instance (case 7, with Crohn's disease) no patient had eye, skin, genitourinary, or bowel symptoms. Radiologically their sacroiliac joints were persistently normal despite symptoms dating back many years in some cases. The identification of an organic basis for the patients' symptoms rested on the scintiscan findings.

As a group these patients showed some differences from the usual pattern seen in ankylosing spondylitis. With 7 men and 8 women there was no male preponderance, and some of the patients were rather older than the average newly diagnosed spondylitic. Only 2 of the 15 patients were positive for HLA B27, a figure no greater than could be expected by chance (normal prevalence for our population 9.2安. (Russell et al., 1974)). Because of these differences it may be that these patients have a rheumatic diseas distinct from ankylosing spondylitis. However, it could equally well be argued that they have the latter condition but that they occupy positions in the mildest extremity of the spondylitic spectrun The paucity of B27-positive individuals might be keeping with the association of B27-negativity with less severe disease (Russell et al., 1976a though this association has been disputed (Khatt et al., 1977).

The greater than expected number of wometi could be regarded as supporting the recent sus gestion that ankylosing spondylitis is underdiagnoseas in women, possibly because it is milder (Calin anid Fries, 1975). Resolution of this problem will require detailed family studies of patients with scintigraphy evidence only of sacroiliitis. Family histories in the present series were generally negative, although $\vec{d}$ patient (case 13) has a son with ankylosing spond litis. The possibility also exists that the sacroiliitis in these patients may be the herald of other diseases for example Crohn's disease, as in case 7. This young woman's diagnosis had been made coiff cidentally at laparotomy following a motor acciden and only later did she develop first backache an then bowel symptoms.

In comparing the original SI:S ratios with tho obtained at follow-up for all the patients whom believe to have inflammatory back disease (that is, cases $1,2,3$, and 5 to 19) we found that the majorit showed improvement. Of the 18 patients 13 showed improvement bilaterally (to complete normality 6), 3 showed improvement in 1 joint, and 2 ha deteriorated. One of the last-mentioned had failed respond to anti-inflammatory drugs and the other was symptomatic and taking no treatment. The mean SI:S ratio originally was $1.46 \pm 0 \cdot \frac{1}{1}$ (standard deviation) while that at follow-up was $1 \cdot 33 \pm 0 \cdot 16$. The difference is statistically sign ficant $(\mathrm{n}=18, t=3 \cdot 14, \mathrm{P}<0 \cdot 005)$. It has been show that in the short term anti-inflammatory therars can induce a return towards normal in the sacroiliăs scan of ankylosing spondylitics (Namey et al., 1971 and our results suggest that such improvement maj persist for long periods. A similar phenomenot has been observed in acute Reiter's syndron (Russell et al., 1977).

While quantitative scintigraphy is a valuable technique for establishing the presence of sacro iliitis, the finding of raised SI:S ratios is clearly not specific for this condition. This fact is best illustrated by case 4 ,' who had undoubted 'degenerative disease. This patient is of further interest in that he develop radiological changes that were interpreted as sacrg 
iliitis. While this has been reported to occur with osteoarthrosis of the hip and knee joints (Moll, 1976), it may simply be an illustration of the difficulty that may be experienced in distinguishing inflammatory from degenerative changes in this area (Resnick et al., 1977). This patient and those listed in Table 4 differ from the others previously discussed in that their symptoms did not suggest inflammatory back disease. Thus, the perhaps obvious statement should be made that the scan data must be interpreted in the light of the clinical findings. In cases 4, 20, 21, and 22. the scan abnormalities could be attributed to trauma or mechanical factors. Case 23 may possibly belong to the inflammatory group, but in the absence of symptoms it is difficult to know how precisely to classify her. Case 24 may have no organic disease at all, since his initial scan was only just within the abnormal range.

From this investigation we conclude that the abnormal sacroiliac scintiscan may in some cases presage the development of ankylosing spondylitis. In a larger group of patients it serves to identify the presence of sacroiliac disease that is not (or not yet) detectable radiologically. Finally, it must be borne in mind that the bone scan reflects osteoblastic activity (Lentle et al., 1976) but it not diagnostic of any specific disease entity. It is therefore essential that all clinical circumstances be carefully assessed when interpreting scintiscan results.

\section{References}

Barraclough, D., Russell, A. S., and Percy, J. S. (1977). Psoriatic spondylitis: a clinical, radiological and scintiscan survey. Journal of Rheumatology, 4, 282-287.

Bennett, P. H., and Wood, P. N. H. (1968). Third International Symposium on Population Studies of the Rheumatic Diseases. p. 456. Excerpta Medica Foundation: Amsterdam.

Calin, A., and Fries, J. F. (1975). Striking prevalence of ankylosing spondylitis in 'healthy' W27 positive males and females. New England Journal of Medicine, 293, 835839.
Davis, P., Thomson, A. B. R., and Lentle, B. C. (in press). Quantitative sacroiliac scintigraphy in patients with Crohn's disease. Arthritis and Rheumatism.

Khan, M. A., Kuschner, I., and Braun, W. E. (1977). Comparison of clinical features in HLA B27 positive and negative patients with ankylosing spondylitis. Arthritis and Rheumatism, 20, 909-912.

Lentle, B. C., Russell, A. S., Percy, J. S., Scott, J. R., and Jackson, F. I. (1976). Bone scintiscanning updated. Annals of Internal Medicine, 84, 297-303.

Lentle, P. C., Russell, A. S., Percy, J. S., and Jackson, F. I. (1977a). The scintigraphic investigation of sacroiliac disease. Journal of Nuclear Medicine, 18, 529-533.

Lentle, B. C., Russell, A. S., Percy, J. S., and Jackson, F. I. (1977b). Scintigraphic findings in ankylosing spondylitis. Journal of Nuclear Medicine, 18, 524-528.

Moll, J. M. H. (1976). Investigation of osteoarthrosis. Clinics in Rheumatic Diseases, 2, 587-613.

Namey, T. C., McIntyre, J., Buse, M., and LeRoy, E. C. (1977). Nucleographic studies of axial spondarthritides. I. Quantitative sacroiliac scintigraphy in early HLA B27 associated sacroiliitis. Arthritis and Rheumatism, 20, 1058-1064.

Ogryzlo, M. A. (1972). Ankylosing spondylitis, in Arthritis and Allied Conditions, 8th edn., p. 699. Edited by J. L. Hollander and D. J. McCarty, Jr. Lea and Febiger: Philadelphia.

Resnick, D., Niwayama, G., and Goergen, T. G. (1977). Comparison of radiographic abnormalities of the sacroiliac joint in degenerative disease and ankylosing spondylitis. American Journal of Roentgenology, 128, 189-196.

Russell, A. S., Schlaut, J., Percy, J. S., and Dossetor, J. B. (1974). HLA (transplantation) antigens in ankylosing spondylitis and Crohn's disease. Journal of Rheumatology, 1, 203-209.

Russell, A. S., Lentle, B. C., and Percy, J. S. (1975). Investigation of sacroiliac disease: comparative evaluation of radiological and radionuclide techniques. Journal of Rheumatology, 2, 45-51.

Russell, A. S., Lentle, B. C., and Schlaut, J. (1976a). Radiologic and scintiscan findings in HLAA B27 negative patients with ankylosing spondylitis. Journal of Rheumatology, 3, 321-323.

Russell, A. S., Lentle, B. C., Percy, J. S., and Jackson, F. I. (1976b). Scintigraphy of sacroiliac joints in acute anterior uveitis. Annals of Internal Medicine, 85, 606-608.

Russell, A. S., Davis, P., Percy, J. S., and Lentle, B. C. (1977). The sacroiliitis of acute Reiter's syndrome Journal of Rheumatology, 4, 293-296. 